\title{
IKTISYAF
}

Volume 1, Nomor 1, Tahun 2019, halaman 33-42

Sekolah Tinggi Ilmu Dakwah (STID) Sirrnarasa

\section{PENGARUH METODE DZIKIR LAA ILAAHA ILLAALLAH TERHADAP AKHLAK SANTRI PUTRI BINAAN}

\author{
Syuhudul Anwar, Ai Nur Syamsyiah \\ Komunikasi Penyiaran Islam STID Sirnarasa
}

syuhud@stidsirnarasa.ac.id

\begin{abstract}
ABSTRAK
Tujuan dari penelitian ini adalah untuk mengetahui dan menganalisis pengaruh metode dzikir Laa Ilaaha Illaallah terhadap akhlak santri putri binaan di Pondok Bustanul Arifat Selangor Malaysia. Metode penelitian yang digunakan adalah metode penelitian kuantitatif deskriptif statistik. Teknik pengambilan sampel dengan menggunakan total sampling dengan jumlah sampel 64 orang. Metode ini digunakan untuk mendeteksi seberapa besar pengaruh pada suatu faktor yang berkaitan dengan satu atau lebih faktor lain berdasarkan pada koefisien korelasi. Data yang ingin diperoleh adalah tinggi rendahnya pengaruh antara variabel X (metode dzikir Laa ilaaha illaallah) terhadap variabel Y (akhlak santri binaan) di Pondok Bustanul Arifat Selangor Malaysia. Angka koefisien korelasi sebesar 0,70 menghasilkan kadar pengaruh metode dzikir Laa ilaaha illaallah terhadap akhlak santri putri binaan sebesar $29 \%$. Ini berarti masih terdapat $71 \%$ dari faktor lain yang memberikan pengaruh terhadap akhlak para santri binaan. Faktor-faktor tersebut adalah kapasitas dasar (IQ), motivasi, kematangan, kebiasaan, lingkungan, masyarakat dan teman pergaulan. Berdasarkan hasil perhitungan angka koefisien korelasi sebesar 0,70 termasuk kedalam kategori tinggi, karena berada pada rentang nilai $0,61-0,80$. Oleh karena itu, hubungan antara variabel $\mathrm{X}$ dengan variabel $\mathrm{Y}$ berkorelasi tinggi. Hasil perhitungan uji hipotesis ternyata $t$ hitung $=7,72$ lebih besar daripada $t$ tabel $=1,67$. Dalam keadaan demikian, maka hipotesis alternatif (Ha) yang diajukan dapat diterima, dengan kata lain terdapat hubungan yang signifikan antara variabel $\mathrm{X}$ dengan variabel $\mathrm{Y}$.
\end{abstract}

Kata kunci: Pengaruh, Akhlak, Putri Binaan 


\section{PENDAHULUAN}

Kemunduran akhlak terjadi karena sebagian besar orang tidak mau lagi mengindahkan tuntunan Agama, yang secara normatif mengajarkan kepada pemeluknya untuk berbuat baik, meninggalkan perbuatan-perbuatan maksiat. Kemunduran akhlak terjadi merupakan akibat dari dampak negatif dari kemajuan tekhnologi dan globalisasi.

Berbagai fenomena menunjukan gejala-gejala yang mengkhawatirkan terkait dengan akhlak generasi bangsa. Fenomena yang mengkhawatirkan tersebut diantaranya bisa kita simak dari berita yang dipublikasikan berbagai media seringkali membuat kita miris mendengarnya. Perkelahian, pergaulan bebas, kasus narkoba, pembunuhan, pemerkosaan, penindasan. Indikator lain yang menunjukan adanya gejala kemunduran akhlak bangsa bisa dilihat dari sopan santun yang kini sudah mulai memudar, diantaranya kita lihat dari cara berbicara, perilaku terhadap sesama dan orang tua, kata-kata kotor yang tidak sepantasnya diucapkan.

Salah satu faktor yang banyak memberikan pengaruh bagi akhlak seseorang adalah lingkungan. Lingkungan yang membentuk akhlak terbagi menjadi tiga, yaitu:

1. Keluarga

Sebagian besar anak dibesarkan oleh keluarga, di samping itu kenyataan menunjukan bahwa di dalam keluarga anak mendapatkan pembinaan yang pertama kali. Pada dasarnya keluarga merupakan lingkungan kelompok sosial yang palig kecil, akan tetapi juga merupakan lingkungan paling dekat dan terkuat dalam mendidik anak terutama bagi anak-anak yang belum memasuki sekolah. Dengan demikian keluarga memiliki pengaruh yang paling mendasar dalam perkembangan akhlak.

2. Sekolah

Walaupun masa anak di sekolah dalam waktu yang terbatas dan relatif singkat, namun kesan yang diterima anak sangat banyak. Sebab sekolah merupakan tempat latihan melaksanakan etiket-etiket dan tatacara yang senantiasa dipatuhi. Sehingga etiket-etiket yang baik menjadi akhlak, baik di sekolah maupun di luar sekolah.

3. Masyarakat

Keadaan masyarakat dan kondisi lingkungan dalam berbagai corak akan berpengaruh terhadap akhlak remaja dimana mereka hidup. Perubahan-perubahan masyarakat yang berlangsung secara cepat dan ditandai dengan peristiwa-peristiwa yang menegangkan. Kondisi masyarakat yang serba tidak menentu tersebut akan mendorong anak untuk melakukan perbuatan-perbuatan tersesat baik menurut penilaian masyarakat, agama, susila dan hukum.

Dizaman yang serba canggih akhlak manusia sedikit banyak telah mengalami pergeseran dan untuk mengembalikannya dibutuhkan upaya perbaikan, baik melalui media dakwah ataupun media yang lain. Banyaknya manusia yang tidak melaksanakan aturan Allah sehingga banyak yang kehilangan pegangan, kehilangan arah dalam kehidupan dan kehilangan arti serta tujuan hidup dengan membawa sejuta persoalan. Hal ini membuat ketidak seimbangan yang tidak sejalan dengan aturan Allah SWT.

Dari uraian di atas dapat dikatakan bahwa remaja yang bermasalah dan banyak menimbulkan kegoncangan, mereka terdorong untuk mencari sesuatu yang mampu memecahkan masalah, bahkan tidak sedikit yang tergoda merasakan kesenangan sesaat dengan menggunakan obat-obatan terlarang sebagai pelarian dari masalah yang dihadapi. Padahal efek narkoba dapat merusak kesehatan secara fisik dan kejiwaan. Narkoba dapat mempengaruhi kemampuan seseorang untuk menjalani hidup sehat dan mengambil keputusan yang benar, kemudian mengganggu komunikasi antar sel saraf. Saat seseorang mulai mengkonsumsi narkoba, terdapat kemungkinan besar untuk mengalami kecanduan. Makin lama pengguna akan membutuhkan dosis yang lebih tinggi demi dapat merasakan efek yang sama, ketika efek narkoba hilang pengguna akan merasa tidak nyaman akibat 
munculnya gejala putus obat dan akan ingin kembali memakainya. Untuk mengatasi persoalan tersebut maka Pondok Bustanul Arifat sebagai tempat rehabilitasi memulihkan kembali dengan Iman yang direalisasikan dalam bentuk pengamalan dzikir untuk menjadi pengendali sikap, ucapan dan tindakan yang nanti berpengaruh besar dalam diri seseorang.

Dzikir salah satu jalan yang mampu menciptakan kondisi ruhaniah manusia mencapai ketenangan serta ketentraman yang tidak dapat diraih oleh peribadatan lainnya. Yang berbeda dengan sholat, zakat, puasa. Masing-masing memiliki kadar batas pencapaian ketenangan yang relatif, bahkan mungkin satu dengan yang lain saling mendukung, dimana berdampak pada akhlak seseorang. Tentunya seseorang yang selalu mengamalkan dzikir Laa ilaaha illaallah dengan yang tidak maka akan nampak perbedaan terhadap akhlaknya.

Penelitian ini timbul dari adanya masalah akhlak yang semakin hari menggejala di kalangan masyarakat, maka dari itu penulis mengambil judul "Pengaruh Metode Dzikir Laa Ilaaha Illaallah Terhadap Akhlak Santri Putri Binaan”. Alasannya karena penulis ingin mengetahui dan menganalisis seberapa besar dzikir Laa ilaaha illaallah memiliki pengaruh terhadap perkembangan akhlak santri binaan. Maka dari itu penulis melakukan penelitian di Pondok Bustanul Arifat Selangor Malaysia.

\section{KAJIAN PUSTAKA}

\section{A. Metode Dzikir}

Metode berasal dari bahasa Yunani Methodos yang berarti cara atau jalan yang ditempuh. Metode adalah prosedur atau cara yang ditempuh untuk mencapai tujuan tertentu. Kemudian ada satu istilah lain yang erat kaitannya dengan dua istilah ini, yakni teknik yaitu cara yang spesifik dalam memecahkan masalah tertentu yang ditemukan dalam melaksanakan prosedur.

Secara etimologi dzikir memiliki arti "Menyebut", "Mengingat". Kata dzikir juga sering didefinisikan dengan menyebut atau mengingat Allah dengan lisan melalui kalimah thayyibah. Arti dzikir yang sebenarnya adalah suatu cara/media untuk menyebut/mengingat nama Allah. Jadi semua bentuk aktivitas yang tujuannya mendekatkan diri kepada Allah dinamakan dzikir, seperti shalat, tetapi lebih spesifik lagi dzikir dibatasi dengan kata mengingat Allah dengan lisan dan hati.

Pada hakikatnya semua anggota tubuh manusia dapat digunakan sebagai dzikir, asalkan untuk bersyukur atau mendekatkan diri kepada Allah, seperti shalat, puasa, zakat, haji. Tetapi para ahli Tashowwuf membagi dzikir itu dengan dua bagian yaitu dzikir jahr dan dzikir khofi, masing-masing memiliki satu metode/cara. Sehubungan dengan metode yang diajarkan oleh para pendahulu yakni Masyayikh Sufi TQN PP. Suryalaya (Syekh Ahmad Shohibul Wafa Tadjul Arifin, Q.S):

a) Dzikir jahr (keras)

Dzikir jahr yaitu dzikir yang diucapkan dengan lisan dan dengan suara keras, kalimat yang digunakan yaitu Lapadz Laa ilaaha illaallah (kalimah thoyyibah), dzikir jahar ini dilaksanakan setelah shalat wajib dengan jumlah bilangan paling sedikit 165x, adapun cara menggunakan dzikir jahar dimulai dengan ucapan Laa dari bawah pusat dan diangkatnya sampai ke otak dalam kepala, sesudah itu diucapkan Ilaaha dari otak dengan menurunkan perlahan-lahan bahu kanan (latifah qalbi). Lalu memulai lagi mengucapkan Illaallah dari bahu kanan dengan menurunkan kepala kepada pangkal dada di sebelah kiri dan berkesudahan pada hati sanubari di bawah tulang rusuk lambung dengan menghujamkan lafadz jalalah (Allah) sekuat mungkin sehingga terasa getaran pada seluruh tubuh. 
b) Dzikir Khafi (rasa)

Dzikir khafi yaitu suatu dzikir yang diucapkan dengan lisan hati setiap detik, dengan menggunakan ismu dzat (Allah). Tujuannya untuk mengajari lidah bathin sehingga pandai berdzikir, akhirnya lidah hati berdzikir sendiri dengan lancar, akal pikiran diikuti rasa kenikmatan, sehingga terjadi nur ilahi masuk ke dalam hati, ingatan semata-mata hanya kepada Allah. Kekuatan dzikir khofi merupakan dasar pokok beribadah, shalat, puasa, zakat dan ibadah lainnya. Bisa jadi benar dan diterima oleh Allah jika dibarengi dengan dzikir khofi.

a. Manfaat Dzikir

Manfaat memiliki dua arti, manfaat adalah sebuah homonim karena artiartinya memiliki ejaan dan pelafalan yang sama tetapi maknanya berbeda. Arti manfaat berarti guna/faedah, diantaranya:

1. Dzikir itu pedang tajam orang beriman "Fainnaz Zikra Saiful Mu'minin". Pedang untuk membasmi, untuk mengusir segala godaan syetan dan bujukan nafsu yang datang dari luar dan yang datang dari dalam. Sekarang, senjata sudah kita miliki, tinggal menggunakannya dengan benar, maka akan terbuka pintu kebahagiaan dunia dan akhirat.

2. Untuk membantu membangunkan hati dari tidurnya, agar hati selalu ingat kepada Allah.

3. Untuk membantu bertambahnya konsentrasi pikiran dan rasa tertuju kepada Allah.

4. Untuk menghilangkan rasa hayalan dalam pikiran.

Sebagaimana hayalan atau ilusi merupakan wujud dari kepalsuan. Secara terminology hayalan berarti ide, keyakinan atau kesan tentang sesuatu yang jelas-jelas keliru. Pada dasarnya berhayal bukan hal yang baik karena dapat membuat orang menjadi bingung dan memiliki tekanan bathin atau bahkan dapat menyebabkan orang menjadi kehilangan jati dirinya dan cenderung gilagilaan.

5. Mampu menghancurkan, menghilangkan dan melembutkan nafsu amarah dan mampu menghilangkan sifat kekufuran serta kemusrikan yang ada dalam hati manusia.

6. Menghapus segala dosa.

7. Benteng pertahanan dari dalam untuk membendung bisikan setan yang bersumpah akan menggoda manusia dari berbagai penjuru.

8. Melembutkan hati yang keras.

9. Menyejukkan hati yang kering.

10. Mententramkan hati yang galau.

11. Bisa mengusir jin dan menjadikannya sangat kecewa.

12. Membuat Allah ridho.

13. Menghilangkan rasa sedih, resah gelisah dalam hati.

14. Membahagiakan dan melapangkan hati.

15. Menguatkan hati dan jiwa raga.

16. Menyinari wajah dan hati.

17. Mempermudah rijki.

18. Mengangkat manusia ke maqam ihsan.

19. Orang-orang yang berdzikir senantiasa dekat dengan Allah.

20. Pembuka semua pintu ilmu.

21. Penyelamat dari adzab Allah.

22. Menghadirkan ketenangan.

23. Menjaga lidah dari perkataan yang dilarang. 
24. Majlis dzikir adalah majlis malaikat.

25. Mendapatkan berkah Allah dimana saja ia berada.

26. Berada dalam naungan Allah SWT.

27. Mendapatkan kebaikan dan anugrah yang tidak terhingga.

28. Didalam dzikir tersimpan kenikmatan surganya dunia.

29. Dzikir adalah cahaya didunia dan akhirat.

30. Dzikir merupakan sebagai sumber kekuatan kalbu dan kemuliaan jiwa.

31. Dzikir merupakan penyatu hati orang yang beriman dan pemecah hati musuhmusuh Allah.

32. Mendekatkan pada akhirat dan menjauhkan dari dunia.

33. Menjadikan hati selalu terjaga.

34. Menjadikan obat hati.

35. Dzikir sebagai modal dasar untuk mencintai Allah.

36. Mendatangkan nikmat dan menolak bala.

37. Menghilangkan rasa takut dan menimbulkan ketenangan jiwa.

38. Membersihkan sifat-sifat munafik.

b. Langkah dan pelaksanaan dzikir antara lain:

1. Memiliki wudhu yang sempurna.

2. Berdzikir dengan pukulan gema yang kuat.

3. Suara keras yang dapat menghasilkan NUR DZIKIR dalam rongga bathin mereka yang berdzikir, sehingga hati mereka itu hidup abadi bersifat keakhiratan.

\section{B. Akhlak}

Menurut Imam Abu Hamid Al Ghazali kata al-khalq "fisik" dan al-khuluq "akhlak" adalah dua kata yang sering dipakai bersamaan. Bahkan Socrates, mu'assisul falsafah al-akhlaqiyah, berkeyakinan bahwa tidak ada sesuatu yang lebih penting bagi manusia dari pada mendidik akhlaknya sebelum berbicara masalah yang lainnya. Sedangkan menurut Farid Ma'ruf mendefinisikan akhlak sebagai kehendak jiwa manusia yang menimbulkan perbuatan dengan mudah karena kebiasaan tanpa memerlukan pertimbangan pikiran terlebih dahulu.

Dengan gambaran teori di atas sangat tepat dan cocok dengan kondisi lingkungan yang penulis teliti, sebab yang menjadikan perubahan pada aspek perilaku adalah dengan adanya amalan dzikir harian yang diharapkan dapat menjadikan pribadi yang lebih baik lagi sehingga akan berdampak pada pemikiran dan sikap seseorang.

Untuk menghindari penafsiran yang keliru terhadap masalah penelitian, maka peneliti perlu menjelaskan kerangka konseptual sesuai dengan judul yang tertera:

1. Pengaruh

Pengaruh merupakan daya yang ada dan timbul dari (orang, benda dsb) yang ikut membentuk watak watak kepercayaan atau perbuatan seseorang. Dalam penelitian ini kita akan lebih mengetahui seberapa besar dzikir Laa ilaaha illaallah berpengaruh terhadap akhlak santri putri binaan di Pondok Bustanul Arifat Selangor Malaysia.

2. Metode dzikir

Metode berasal dari bahasa yunani methodos yang berarti cara atau jalan yang ditempuh. Dzikir memiliki arti "menyebut", "mengingat". Kata dzikir juga sering didefinisikan dengan menyebut atau mengingat Allah dengan lisan melalui kalimat thayyibah. Arti dzikir yang sebenarnya adalah suatu cara/media untuk menyebut/mengingat nama Allah, jadi semua bentuk aktivitas yang tujuannya mendekatkan diri kepada Allah dinamakan dzikir. 


\section{Akhlak}

Secara terminologi berarti tingkah laku seseorang yang didorong oleh suatu keinginan secara sadar untuk melakukan suatu perbuatan. Akhlak berasal dari bahasa Arab khuluq yang jamaknya akhlaq. Menurut bahasa akhlak artinya perangai, tabiat dan agama. Secara sempit, pengertian akhlak dapat diartikan dengan kumpulan kaidah untuk menempuh jalan yang baik, jalan yang sesuai untuk menuju akhlak, pandangan akal tentang kebaikan dan keburukan.

Keadaan jiwa seseorang yang mendorongnya untuk melakukan perbuatan-perbuatan tanpa melalui pertimbangan pikiran terlebih dahulu. Keadaan ini terbagi dua, ada yang berasal dari tabiat aslinya, adapula yang diperoleh dari kebiasaan yang berulang-ulang. Boleh jadi pada mulanya tindakan itu melalui pikiran dan pertimbangan, kemudian dilakukan terusmenerus maka jadilah suatu bakat dan akhlak.

Akhlak adalah daya kekuatan (sifat) yang tertanam dalam jiwa yang mendorong perbuatan yang spontan tanpa memerlukan pertimbangan pikiran. Jadi, akhlak merupakan sikap yang melekat pada diri seseorang dan secara spontan diwujudkan dalam tingkah laku dan perbuatan.

Keadaan jiwa seseorang yang mendorong manusia untuk berbuat tanpa melalui pertimbangan dan pilihan terlebih dahulu. Keadaan tersebut pada seseorang boleh jadi merupakan tabiat atau bawaan, dan boleh jadi juga merupakan kebiasaan melalui latihan dan perjuangan.

4. Santri binaan

Santri adalah bahasa serapan dari bahasa inggris yang berasal dari dua suku kata yaitu sun dan three yang artinya tiga matahari. Matahari adalah titik pusat tata surya berupa bola berisi gas yang mendatangkan terang dan panas pada bumi di siang hari. Seperti kita ketahui matahari adalah sumber energi tanpa batas, matahari pula sumber kehidupan bagi seluruh tumbuhan dan semuanya dilakukan secara ikhlas oleh matahari.

Binaan adalah istilah dari inabah yang berasal dari bahasa arab anaba yunibu (mengembalikan) sehingga inabah berarti pengembalian atau pemulihan, maksudnya proses kembalinya seseorang dari jalan yang menjauhi Allah ke jalan yang mendekatkan kepada Allah SWT.

\section{METODE PENELITIAN}

Jenis penelitian yang digunakan dalam penelitian ini adalah penelitian Deskriptif statistik. Penelitian deskriptif statistik dimaksudkan untuk mengumpulkan informasi mengenai status suatu gejala yang ada, yaitu keadaan gejala menurut apa adanya pada saat penelitian dilakukan, dan juga dilakukan pengukuran.

Metode penelitian yang digunakan dalam penelitian ini adalah metode survey. Survey merupakan penelitian yang dilakukan pada populasi besar maupun kecil, tetapi data yang dipelajari adalah data dari sampel yang diambil dari populasi tersebut, sehingga ditemukan kejadian-kejadian relatif, distribusi dan hubungan antar variabel sosiologis maupun psikologis. Metode survey digunakan dengan mengambil contoh dari suatu populasi. Hal ini dilakukan dengan alasan sebagai berikut:

a. Metode survey lebih cepat dengan biaya rendah.

b. Memberikan informasi lebih lengkap (Komprehensif).

c. Memberikan hasil dengan ketelitian lebih tinggi.

d. Memungkinkan dengan penghematan waktu dan biaya maka contoh survey dapat menggunakan populasi-populasi lebih besar dengan berbagai jenis variasi. 
Metode ini digunakan untuk mendeteksi seberapa besar pengaruh pada suatu faktor yang berkaitan dengan satu atau lebih faktor lain berdasarkan pada koefisien korelasi. Data yang ingin diperoleh adalah tinggi rendahnya pengaruh antara variabel $\mathrm{X}$ (metode dzikir Laa ilaaha illaallah) terhadap variabel Y (akhlak santri binaan) di Pondok Bustanul Arifat Selangor Malaysia.

\section{HASIL DAN PEMBAHASAN}

Penganalisisan data dibagi menjadi dua tahap. Pertama dengan analisis parsial dan kedua dengan analisis korelasional.

1. Analisis Parsial

Penganalisisan ini pada dasarnya merupakan tahapan awal untuk memberikan gambaran tentang realitas variabel $\mathrm{X}$, yaitu pengaruh metode dzikir di Pondok Bustanul Arifat Selangor Malaysia dan realitas variabel Y, yaitu perkembangan akhlak santri binaan. Dalam tahapan penganalisisan ini digunakan langkah-langkah sebagai berikut:

a. Menghitung jumlah skor yang diperoleh tiap-tiap responden.

b. Menentukan skor mentah dari tiap-tiap item yang diperoleh responden.

c. Menentukan nilai rata-rata, dengan rumus:

$$
M=\frac{\Sigma f_{i} X_{i}}{\Sigma f_{i}}
$$

d. Menginterpretasikan nilai rata-rata kedalam skala normal absolut berikut ini.

$0,5-1,5$ berarti sangat rendah

$1,6-2,5$ berarti rendah

$2,6-3,5$ berarti sedang

$3,6-4,5$ berarti tinggi

$4,6-5,5$ berarti sangat tinggi

e. Uji Normalitas

Proses pengujian ini dimaksudkan untuk mengetahui normal atau tidaknya distribusi masing-masing variabel, adapun langkah-langkahnya sebagai berikut:

1) Menentukan rentang, rumusnya:

$$
\mathrm{R}=(\mathrm{Xt}-\mathrm{Xr})+1
$$

2) Menentukan banyak kelas interval, rumusnya:

$$
\mathrm{K}=1+(3,3) \log \mathrm{n}
$$

3) Menentukan panjang kelas interval $(\mathrm{P})$, dengan rumus:

$$
\mathrm{P}=\mathrm{R}: \mathrm{K}
$$

4) Membuat tabel distribusi frekuensi

5) Menentukan tendensi sentral

a. Menentukan nilai rata-rata (Mean), dengan rumus:

$$
M=\frac{\sum f x}{N}
$$

b. Menentukan nilai median (Me), dengan rumus:

$$
M d=B b+\left(\frac{1 / 2 n-f k b}{F d}\right) . x i
$$

c. Menentukan nilai modus (Mo), dengan rumus:

$$
\mathrm{Mo}=3 \mathrm{Md}-2 \mathrm{M}
$$

d. Menginterpretasikan tendesi sentral

6) Menentukan nilai standar deviasi (SD), dengan rumus: 


$$
S D=\sqrt{\frac{\sum f x^{2}}{N}-\left(\frac{\sum f x}{N}\right)^{2}}
$$

7) Membuat tabel distribusi observasi dan ekspetasi masing-masing variabel.

8) Menentukan harga chi kuadrat hitung dengan rumus:

$$
X^{2}=\sum_{i=1}^{K} \frac{(O i-E i)^{2}}{E i}
$$

9) Menentukan derajat kebebasan (dk), rumusnya:

$$
\mathrm{Dk}=\mathrm{K}-3
$$

10) Menentukan chi kuadrat tabel $\left(X^{2}\right.$ tab) pada taraf signifikansi $5 \%$.

11) Menginterpretasikan hasil pengujian normalitas pada ketentuan dibawah ini:

- Data di atas dikatakan normal, jika harga $X^{2}$ hitung lebih kecil daripada $\mathrm{X}^{2}$ tabel.

- Data di atas dikatakan tidak normal, jika harga $X^{2}$ hitung lebih besar daripada harga $\mathrm{X}^{2}$ tabel.

2. Analisis Korelasional

Untuk penganalisisan ini ditempuh langkah-langkah sebagai berikut:

a. Mengurutkan data masing-masing variabel sesuai dengan pasangannya.

b. Menentukan persamaan regresi linier, rumusnya:

$$
\begin{aligned}
\mathrm{Y} & =\mathrm{a}+\mathrm{b}(\mathrm{X}) \text { dimana: } \\
a & =\frac{\left(\sum Y\right)\left(\sum X^{2}\right)-\left(\sum X\right)\left(\sum X Y\right)}{n \sum X^{2}-\left(\sum X\right)^{2}} \\
b & =\frac{n \sum X Y-\left(\sum X\right)\left(\sum Y\right)}{n \sum X^{2}-\left(\sum X\right)^{2}}
\end{aligned}
$$

c. Menentukan linieritas regresi dengan menempuh langkah-langkah sebagai berikut:

1. Menentukan jumlah kuadrat regresi a $\left(\mathrm{JK}_{\mathrm{a}}\right)$ :

$$
J K_{a}=\left(\sum Y\right)^{2}: n
$$

2. Menentukan jumlah kuadrat arah regresi b terhadap a $\left(\mathrm{JK}_{\mathrm{b} / \mathrm{a}}\right)$ :

$$
J K_{b / a}=b \sum X Y-\frac{\left(\sum X\right)\left(\sum Y\right)}{n}
$$

3. Menentukan jumlah kuadrat residu $\left(\mathrm{JK}_{\mathrm{r}}\right)$ :

$$
\mathrm{JK}_{\mathrm{r}}=\sum Y^{2}-J K_{a}-J K_{b / a}
$$

d. Penghitungan koefisien korelasi

1. Jika kedua variabelnya berdistribusi normal dan regresinya linier, maka rumus korelasi yang digunakan adalah rumus korelasi pearson't Product momen't yaitu:

$$
{ }^{r} X Y=\frac{N \sum X Y-\left(\sum X\right)\left(\sum Y\right)}{\sqrt{\left\{N \sum X^{2}-\left(\sum X\right)^{2}\right\}\left\{N \sum Y^{2}-\left(\sum Y\right)^{2}\right\}}}
$$

2. Jika salah satu atau kedua variabelnya berdistribusi tidak normal atau regresinya tidak linier, maka rank dari Spearman, yaitu:

$$
{ }^{r h o} X Y=1 \frac{6 \sum D^{2}}{N\left(N^{2}-1\right)}
$$


e. Pengujian signifikansi korelasi

Langkah yang ditempuh dalam pengujian ini sebagai berikut:

1. Menentukan harga t hitung, rumusnya:

$$
t=\frac{\sqrt{n-2}}{\sqrt{1-r^{2}}}
$$

2. Menentukan derajat kebebasan (dk), rumusnya:

$$
\mathrm{Dk}=\mathrm{n}-2
$$

3. Menentukan harga t tabel pada taraf signifikansi $5 \%$.

4. Menentukan keberartian korelasi, dengan kriteria sebagai berikut:

a) Jika nilai $\mathrm{t}$ hitung lebih besar daripada $\mathrm{t}$ tabel, maka korelasinya signifikan.

b) Jika nilai t hitung lebih kecil dari t tabel, maka korelasinya tidak signifikan.

Setelah diuji dengan rumus t, ternyata hipotesis menyatakan bahwa semakin sering santri binaan dalam mengamalkan dzikir di Pondok, maka akan semakin besar pengaruh terhadap perkembangan akhlaknya. Artinya, terdapat hubungan yang signifikan antara dzikir dengan akhlak. Dilihat dari tinggi rendahnya hubungan korelasi, angka tersebut berada pada rentang nilai $0,61-0,80$, berarti termasuk korelasi tinggi. Angka koefisien korelasi sebesar 0,70 itu juga menghasilkan kadar pengaruh metode dzikir laa ilaaha illaallah terhadap akhlak santri putri binaan sebesar $29 \%$. Ini berarti masih terdapat $71 \%$ dari faktor lain yang memberikan pengaruh terhadap akhlak para santri binaan. Faktorfaktor tersebut adalah kapasitas dasar (IQ), motivasi, kematangan, kebiasaan, lingkungan, masyarakat dan teman pergaulan.

Adapun hasil perolehan skor dari 64 santri binaan berdasarkan hasil tes formatif dapat dilihat dalam lampiran tentang data variabel Y. Untuk keperluan analisisnya, maka setiap item soal diberi nilai 2 (dua) apabila jawabannya benar, dan nilai 0 (nol) apabila jawabannya salah. Dengan mengacu pada nilai setiap item, maka akan diperoleh skor ideal tertinggi $30 \times 2=60$, dan skor terendah $30 \times 0=0$.

Untuk menghitung hubungan antara variabel $\mathrm{X}$ dan variabel $\mathrm{Y}$, digunakan rumus product moment. Dari hasil perhitungan (lampiran 10) diperoleh koefisien korelasi sebesar 0,70. Angka koefisien sebesar itu menghasilkan harga t hitung sebesar 7,72 dan t tabel sebesar 1,67 pada taraf signifikansi $5 \%$. Sehingga $t$ hitung $>t$ tabel, hal ini berarti terdapat hubungan yang meyakinkan antara metode dzikir terhadap perkembangan akhlak santri binaan. Hal ini juga berarti hinol (Ho) ditolak sedangkan hipotesis alternatif (Ha) diterima. Oleh karena arah korelasinya positif, maka diinterpretasikan bahwa semakin banyak mengamalkan dzikir maka akan semakin besar pula pengaruhnya terhadap perkembangan akhlak santri binaan

\section{KESIMPULAN}

Pada bab terakhir ini, penulis akan menyimpulkan hasil dari penelitian mengenai pengaruh metode dzikir Laa ilaaha illaallah terhadap akhlak santri putri binaan di Pondok Bustanul Arifat Selangor Malaysia, adapun kesimpulannya adalah sebagai berikut:

1. Realitas metode dzikir yang diterapkan di Pondok Bustanul Arifat dapat dilihat dari hasil perhitungan statistik termasuk dalam kategori sedang. Hal ini ditunjukan oleh nilai rata-rata jawaban mereka terhadap 15 item angket yang menghasilkan angka sebesar 3,37. Dengan mengacu pada penjabaran rentang nilai terendah 0,5 dan nilai tertinggi 5,5. Angka tersebut termasuk pada kategori sedang, karena berada pada interval 2,6-3,5. 
2. Realitas akhlak para santri binaan ditunjukan oleh hasil perhitungan statistik yang mencapai nilai rata-rata sebesar 6,6. Angka tersebut termasuk dalam kategori cukup, karena berada pada rentang nilai $6-6,9$. Jadi dapat diambil suatu kesimpulan bahwa perkembangan akhlak para santri binaan di Pondok Bustanul Arifat Selangor Malaysia adalah sedang.

3. Hubungan antara metode dzikir yang diamalkan di Pondok Bustanul Arifat dengan perkembangan akhlak santri putri binaan ternyata menghasilkan angka koefisien korelasi sebesar 0,70. Setelah diuji dengan rumus t, ternyata hipotesis yang menyatakan bahwa semakin sering santri binaan dalam mengamalkan dzikir di Pondok, maka akan semakin besar pengaruh terhadap perkembangan akhlaknya. Artinya, terdapat hubungan yang signifikan antara dzikir dengan akhlak. Dilihat dari tinggi rendahnya hubungan korelasi, angka tersebut berada pada rentang nilai $0,61-0,80$, berarti termasuk korelasi tinggi. Angka koefisien korelasi sebesar 0,70 itu juga menghasilkan kadar pengaruh metode dzikir Laa ilaaha illaallah terhadap akhlak santri putri binaan sebesar $29 \%$. Ini berarti masih terdapat $71 \%$ dari faktor lain yang memberikan pengaruh terhadap akhlak para santri binaan. Faktor-faktor tersebut adalah kapasitas dasar (IQ), motivasi, kematangan, kebiasaan, lingkungan, masyarakat dan teman pergaulan.

\section{Saran}

Berdasarkan pada hasil penelitian yang telah diuraikan sebelumnya dengan tanpa melupakan segala keterbatasan dan kekurangan-kekurangan yang dirasakan dalam penelitian ini, maka peneliti akan mengemukakan beberapa saran yang berkaitan dengan hasil penelitian ini yang mungkin dapat dijadikan sebagai bahan masukan atau bahan pertimbangan bagi pihak-pihak yang memerlukan, diantaranya:

1. Akhlak yang baik akan terlahir dari kebiasaan yang baik, namun untuk terwujudnya insan yang berakhlak tidak bisa instan, semua perlu proses, perlu pembinaan, perlu adanya bimbingan, dengan dibiasakan mengamalkan dzikir insyaallah seiring berjalannya waktu akan terbiasa dan akan terlahir akhlak yang mulia.

2. Perlu adanya kesadaran dari diri sendiri untuk mewujudkannya, karena dalam Islam tidak ada paksaan, agar semuanya menjadi ibadah dimulai dengan niat yang baik.

3. Bagi orang tua untuk jangan pernah lelah dalam membimbing, mengarahkan dan mengingatkan kepada anak-anaknya dalam segala hal termasuk dalam ibadah, karena salah satu yang mempengaruhi akhlak anak adalah perhatian dari orang tuanya sendiri.

\section{DAFTAR PUSTAKA}

Abdullah, Yatimin. 2007. Study Akblak Dalam Perspektif Al-Qur'an

Al-Ghazali. 1994. Ibya Ulumudin. Bandung.

Arikunto, Suharsimi. 1996. Prosedur Penelitian Suatu Pendekatan Praktek. Jakarta

Lidi, Amin. 2012. Suryalaya Bukan Panggung Sandiwara. Semarang.

Mas'ud, Ali. 2012. Akblak Thashownf. Sidoarjo:CV Dwiputra Pustaka Jaya 